\title{
PROTOTIPE MEDIA PEMBELAJARAN BERBASIS ANDROID UNTUK MEMBACA PERMULAAN
}

\author{
Indah Puji Astuti \\ Fakultas Teknik, Program Studi Teknik Informatika \\ Universitas Muhammadiyah Ponorogo \\ Email: indahsan.0912@gmail.com \\ Dwiyono Ariyadi \\ Fakultas Teknik, Program Studi Teknik Informatika \\ Universitas Muhammadiyah Ponorogo \\ Email: ayick19@gmail.com \\ Lilis Sumaryanti \\ Fakultas Pendidikan Agama Islam, Program Studi PGMI \\ Universitas Muhammadiyah Ponorogo \\ Email: listylilis@gmail.com
}

\begin{abstract}
ABSTRAK
Belajar dimanapun dan kapanpun merupakan kebutuhan manusia, tidak terlepas dari kewajiban belajar, suasana belajar merupakan peran pendukung yang tidak bisa diabaikan. Untuk menimbulkan suasana belajar yang bisa diterima di situasi apapun adalah didukung dengan adanya media pembelajaran. Banyak media pembelajaran yang sudah ada sekarang ini, ada yang gratis dan berbayar. Namun pembelajaran yang tersedia secara gratis tersebut masih sedikit yang mengacu ke kurikulum sesuai tingkatan pendidikan. Media pembelajaran dalam bentuk aplikasi berbasis android yang materinya mengacu sesuai kurikulum untuk tingkat dasar MI/SD masih jarang dijumpai. Tujuan dari penelitian ini adalah untuk membuat prototipe media pembelajaran yang sesuai dengan kurikulum peserta didik. Keunggulan dari aplikasi media pembelajaran ini lebih terstruktur karena berpedoman pada kurikulum pembelajaran Bahasa Indonesia kelas 1 di tingkat MI/SD pada materi membaca permulaan. Penelitian ini mengadopsi metode pengembangan sistem waterfall untuk pengembangan aplikasinya, dimulai dari tahap analisis sampai pengujian. Pengujian terhadap aplikasi menggunakan metode black box testing. Hasil pengujian menunjukkan bahwa menu-menu yang terdapat pada aplikasi ini telah berjalan dengan baik sesuai dokumen perancangan.
\end{abstract}

Kata kunci: android; black box testing; media pembelajaran; waterfall.

\section{ABSTRACT}

Learning wherever and whenever is a human need, can not be separated from the obligation to learn, the atmosphere of learning is a supporting role that can not be ignored. To build an atmosphere of learning that can be accepted in any situation is supported by learning media. Many learning media that already exist today, there are free and paid. But the learning that is available free of charge is still a little which refers to the curriculum according to the level of education. Learning media with android-based applications whose material refers to the curriculum for the basic level of elementary school is still rarely found. So, the purpose of this research is develop learning media that is in accordance with the curriculum of students. The advantages of this instructional media application are more structured because they are guided by the Indonesian language learning curriculum of class one at the elementary school level on initial reading material. In this research used the Waterfall model to developed aplication, consist of analysis phase until testing phase. Testing of applications using the black box method. The results of this research are the black box method show that all the menus contained in this application are running in accordance with the design document.

Keywords: android, black box testing, learning media, waterfall.

\section{PENDAHULUAN}

Siapa saja yang ingin maju dan menambah pengetahuan dalam segara hal diantaranya dapat dilakukan dengan cara membaca. Menurut Lado (dalam Tarigan 2008:9) membaca diartikan memahami dan menguasai polapola bahasa dari gambaran tertulisnya. Biasanya pemahaman pola-pola dasar ini dipelajari oleh anak kelas rendah dan dikenal dengan istilah membaca permulaan [1]. 
Tahapan dalam membaca permulaan dibedakan menjadi dua, yaitu tanpa buku dan dengan buku [2]. Membaca permulaan tanpa buku maksudnya adalah membaca dapat dilakukan dengan beberapa cara, diantaranya menggunakan media gambar, menceritakan media gambar yang disediakan dengan bahasa sendiri, memperkenalkan pola dan bentuk tulisan dengan bantuan gambar tersebut, membaca tulisan berdasarkan gambar, membaca tulisan tanpa gambar. Sedangkan membaca permulaan dengan buku maksudnya adalah guru dituntut untuk menumbuhkan motivasi dengan menarik minat dan perhatian siswa terhadap buku yang akan dibacanya sesuai kemauan diri sendiri tanpa ada orang lain yang memaksa untuk membaca.

Kemampuan membaca permulaan ini sebaiknya dilakukan dengan perasaan senang hati sehingga siswa tidak merasa dibebani dengan perintah maupun tugas yang terkesan memaksanya. Di era digitalisasi, proses bermain tidak hanya dikategorikan dengan permainan yang mengandalkan kekuatan fisik saja akan tetapi bisa juga menggunakan aplikasi android. Kekreatifan guru dalam menginovasikan metode pembelajaran sangat berperan penting dalam proses pembelajaran. Masih banyaknya proses membaca permulaan yang terkesan monoton pada siswa kelas rendah di sekolah-sekolah menjadi faktor utama dalam pelaksanaan penelitian ini.

Hasil wawancara pada beberapa mahasiswa PGMI FAI Unmuh Ponorogo yang mayoritas berprofesi sebagai guru MI/SD tentang metode yang digunakan dalam pembelajaran membaca permulaan, mayoritas dari para guru MI/SD tersebut masih menggunakan metode dekte dan ada yang memanfaatkan media buku saja (majalah) bahkan tanpa dilengkapi gambar yang menarik. Ini menyebabkan siswa merasa bosan dan tidak fokus pada waktu pelaksanaan membaca permulaan dalam mata pelajaran Bahasa Indonesia khususnya materi pembentukan kalimat tunggal dan melengkapi kalimat sederhana. Dalam hal ini siswa terkesan hanya membayangkan jawaban dan adanya keterpaksaan`sehingga membuat mereka merasa terbebani dalam mengerjakannya tanpa memahami maksud dari pertanyaan yang diberikan pada bacaan yang telah dibaca.

Pada tahun 2016 Fredyana dan Dewanto telah mengembangkan media pembelajaran menggunakan androidbased untuk mendukung pelajaran teknologi dasar otomotif. Aplikasi ini dibuat untuk para siswa kelas X SMK Negeri 3 Buduran Sioarjo. Penerapan media pembelajaran mendapat respon positif dari siswa dan dikategorikan sangat baik serta dengan menggunakan media ini hasil belajar siswa meningkat [3].

Rusdi pada tahun 2016 telah mengembangkan media pembelajaran "ChemBird" berbasis android untuk materi kimia. Studi kasus penelitian ini adalah SMA di Makassar kelas XI. Hasil pada penelitian ini menjelaskan bahwa respon siswa dan guru terhadap aplikasi adalah tentang kepraktisan dan keefektifan aplikasi dimana kemampuan guru dalam mengolah pembelajaran dikategorikan tinggi [4].

Pangestika dkk pada tahun 2017 membuat aplikasi android untuk mata pelajaran bahasa Inggris. Media pembelajaran ini ditujukan untuk siswa kelas dasar. Hasil penelitiannya menjelaskan bahwa hampir $90 \%$ siswa yang menggunakan aplikasi android tersebut dapat memahami materi dengan mudah [5].

Dari beberapa penelitian sebelumnya di atas menunjukkan bahwa aplikasi berbasis android yang digunakan untuk media pembelajaran dapat membantu proses belajar mengajar siswa maupun guru. Dengan tampilan yang lebih menarik dan tidak monoton karena lebih interaktif. Hal ini merupakan salah satu alasan kenapa aplikasi media pembelajaran ini dikembangkan.

Media pembelajaran digital yang populer digunakan di Indonesia diantaranya berbasis web dan android. Banyak aplikasi pembelajaran berbasis android yang dapat diakses secara gratis. Namun pembelajaran yang tersedia secara gratis tersebut masih sedikit yang mengacu ke kurikulum sesuai tingkatan pendidikan termasuk tingkat dasar MI/SD. Sebagian besar disajikan dengan konsep dan ejaan bahasa inggris, tentunya hal ini tidak sesuai dengan cara membaca ejaan bahasa Indonesia yang benar. Demikian gambaran situasi yang dialami oleh sebagian besar guru tingkat dasar MI/SD kelas 1 di kabupaten Ponorogo khususnya pada materi belajar membaca bahasa Indonesia. Guru pengajar tingkat dasar sendiri sebagian besar juga belum mampu membuat aplikasi media pengajaran yang bisa berjalan dengan platform android, padahal aplikasi berbasis android sangat diminati oleh pengguna karena kemudahan dalam mengaksesnya.

Dari permasalahan diatas maka dapat diambil perumusan masalah yaitu bagaimana membuat prototipe media pembelajaran untuk materi belajar membaca pemulaan berbasis android. Aplikasi yang akan dibangun mengacu ke kurikulum MI/SD dan disajikan dengan ejaan bahasa Indonesia serta gambar yang menarik. Sebelum di gunakan oleh peserta didik akan dilakukan pengujian terhadap aplikasi menggunakan Black box testing. Diharapkan aplikasi ini nantinya dapat diterima dengan baik oleh pengguna yaitu peserta didik MI/SD.

\section{METODOLOGI PENELITIAN}

Penelitian ini mengadopsi tahapan-tahapan yang ada pada model pengembangan sistem waterfall. Ada 4 tahapan yang dilakukan yaitu melakukan analisis, desain, coding, dan pengujian [6]. Adapun penjelasan dari tiaptiap tahapan dalam penelitian ini adalah sebagai berikut :

\subsection{Analisis}

Ada 3 fase yang dilakukan pada tahap analisis dalam penelitian ini yaitu : 


\section{a. Mendefinisikan masalah}

1) Selama ini metode belajar siswa masih menggunakan media pembelajaran seperti buku dan papan tulis dengan cara guru menerangkan langsung di depan kelas untuk mengajar membaca.

2) Banyak siswa yang merasa cepat bosan ketika guru menerangkan.

3) Banyak siswa ketika disuruh untuk membaca buku, sebagian akan menjawab malas, mengantuk dan beberapa alasan lainnya.

b. Mendefinisikan solusi alternatif penyelesaian masalah

Membuat aplikasi yang dengan konsep android-based dengan tampilan yang user frienly dan interaktif untuk menarik minat siswa belajar.

\section{c. Mendefinisikan kebutuhan sistem}

Kebutuhan Fungsional

1) Aplikasi dapat menampilkan abjad beserta suara cara pelafalannya

2) Aplikasi dapat menampilkan kata yang terdiri atas 3 macam kata yaitu (kata benda, kata kerja dan warna) beserta suara cara pelafalannya

3) Aplikasi dapat menampilkan kalimat beserta suara cara pelafalannya

4) Aplikasi dapat menampilkan kuis tebak abjad dan menampilkan skor

5) Aplikasi dapat menampilkan kuis pilihan ganda dan menampilkan skor

6) Aplikasi dapat menampilkan kuis essay dan menampilkan skor

7) Kebutuhan Non Fungsional

8) Notebook dengan Prosesor Intel(R) Core(TM) i5, Speed 1.6GHz Turbo Core 2.6Ghz

9) Wifi untuk koneksi internet

\subsection{Desain}

Pada penelitian ini, tahapan desain terdiri dari 2 fase yaitu membuat Use Case Diagram dan membuat Desain Interface.

\subsection{Coding}

Pada tahapan ini dimulai membuat baris-baris program.

\subsection{Pengujian}

Pada tahap pengujian dilakukan uji coba terhadap menu-menu yang ada dalam media pembelajaran berbasis Android dengan metode pengujian black box testing. Menu-menu diuji coba apakah sudah berjalan sesuai dengan fungsinya.

Kerangka penelitian untuk membuat prototype aplikasi media pembelajaran berbasis android untuk membaca permulaan dapat dilihat pada Gambar 1.

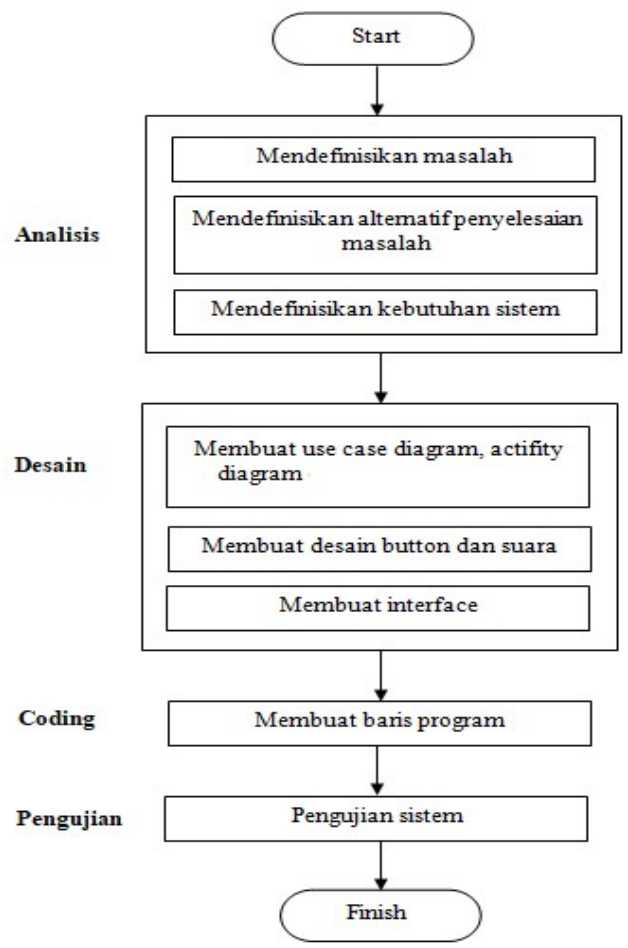

Gambar 1. Kerangka Pemikiran 


\section{HASIL DAN PEMBAHASAN}

\subsection{Use Case Diagram}

Dibuat untuk mengetahui hubungan antara fungsional sistem dengan aktor pemakainya. Untuk mendefinisikan terdiri dari fungsi apa saja dalam suatu sistem serta siapa saja yang dapat menjalankan fungsi tersebut [7]. Use case diagram untuk aplikasi membaca permulaan dapat dilihat pada Gambar 2.

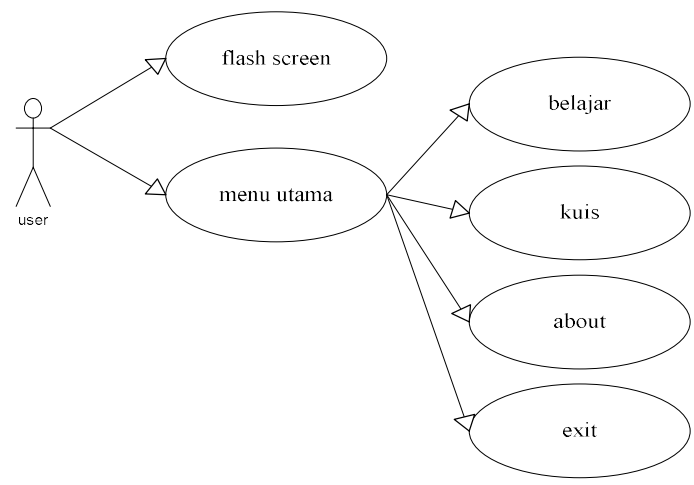

\section{Gambar 2. Use Case Diagram Aplikasi Membaca Permulaan}

Use case diagram aplikasi ini menunjukkan bahwa user dapat melihat flash screen dan juga menu utama. Di dalam menu utama terdapat 4 sub menu yaitu belajar, kuis, about dan exit.

\subsection{Activity Diagram}

Diagram aktifitas ini digunakan untuk menggambarkan urutan tahapan proses yang ada dalam aplikasi [8]. Aplikasi ini memiliki 2 activity diagram yaitu Belajar dan Kuis. Gambar 3 adalah activity diagram untuk bagian Belajar.

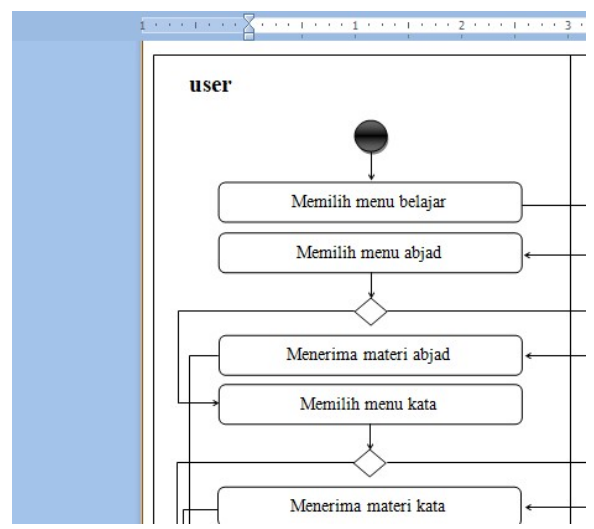

Gambar 3 Activity Diagram Belajar

\subsection{Desain Interface}

Perancangan interface aplikasi membaca permulaan dapat dilihat pada Gambar 4-Gambar 10.

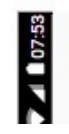

Gambar 4. Tampilan Menu Utama Aplikasi Membaca Permulaan

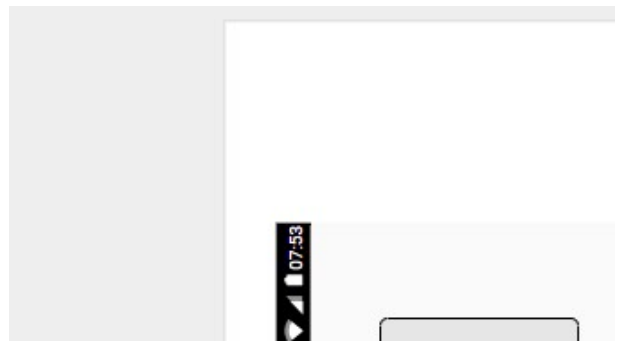

Gambar 5. Tampilan Menu Belajar Aplikasi Membaca Permulaan 


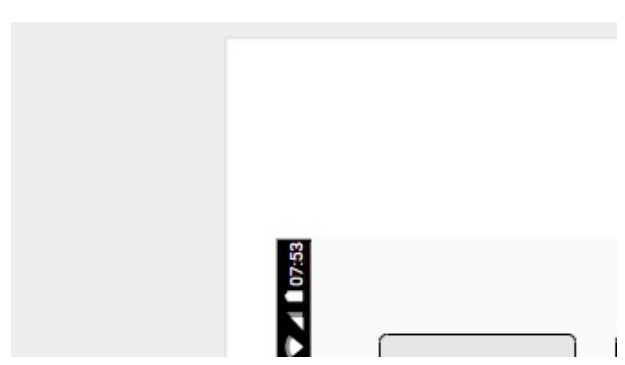

Gambar 6. Tampilan Menu Pilihan Kuis Aplikasi Membaca Permulaan

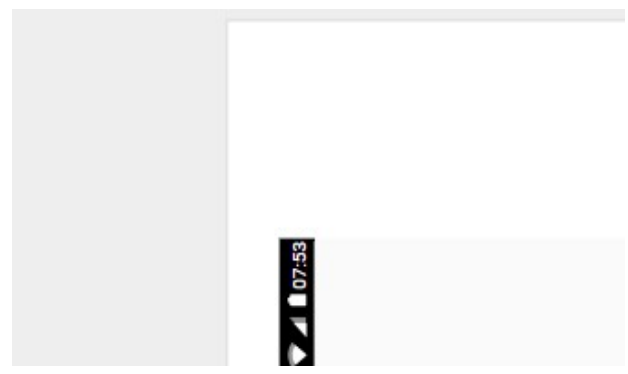

Gambar 9. Tampilan Menu Kuis2 Aplikasi Membaca Permulaan

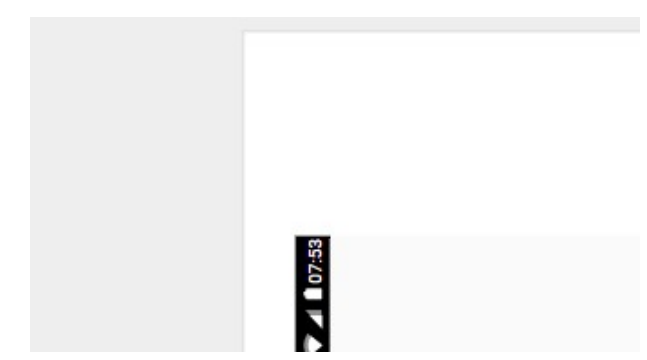

Gambar 7. Tampilan Menu Abjad Aplikasi Membaca Permulaan

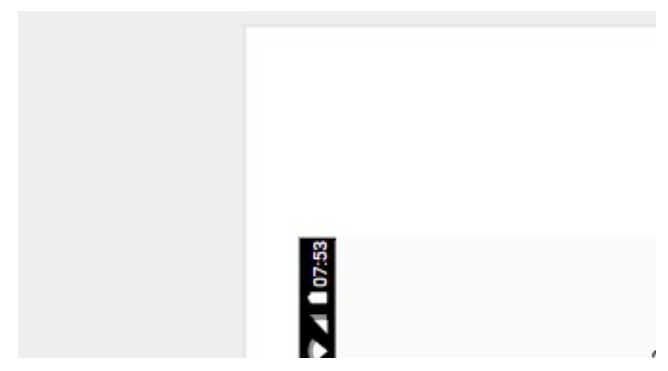

Gambar 4.10 Tampilan Menu Kuis3 Aplikasi Membaca Permulaan

\subsection{Pengujian sistem}

Pengujian dilakukan terhadap menu-menu yang ada dalam media pembelajaran berbasis Android dengan metode pengujian black box testing. Menu-menu diuji coba apakah sudah berjalan sesuai dengan fungsinya. Hasil uji coba terhadap beberapa menu yang ada dalam aplikasi media pembelajaran membaca tingkat dasar dapat dilihat pada Tabel 1.

Tabel 1. Pengujian Menu

\begin{tabular}{|c|c|c|c|c|}
\hline $\begin{array}{c}\text { Data } \\
\text { Masukkan }\end{array}$ & $\begin{array}{l}\text { Harapan } \\
\text { Keluaran }\end{array}$ & $\begin{array}{c}\text { Hasil } \\
\text { pengamata } \\
\mathbf{n}\end{array}$ & Tampilan & Kesimpulan \\
\hline $\begin{array}{l}\text { Tombol } \\
\text { abjad }\end{array}$ & $\begin{array}{l}\text { Gambar huruf kecil } \\
\text { di tengah akan } \\
\text { muncul beserta suara } \\
\text { menyesuaikan } \\
\text { pilihan abjad yang } \\
\text { ditekan di bawahnya }\end{array}$ & $\begin{array}{l}\text { Tampil } \\
\text { huruf kecil } \\
\text { ditengah } \\
\text { disertai } \\
\text { suara } \\
\text { pelafalan. } \\
\text { Disini terdiri } \\
\text { dari huruf A } \\
\text { - Z dan } \\
\text { berfungsi } \\
\text { semua }\end{array}$ & & Sesuai \\
\hline $\begin{array}{l}\text { Tombol } \\
\text { kata benda }\end{array}$ & $\begin{array}{l}\text { Gambar benda di } \\
\text { tengah dengan cara } \\
\text { pelafalannya akan } \\
\text { muncul beserta suara } \\
\text { menyesuaikan } \\
\text { pilihan gambar yang } \\
\text { ditekan di bawahnya }\end{array}$ & $\begin{array}{l}\text { Tampil } \\
\text { gambar } \\
\text { benda } \\
\text { ditengah } \\
\text { disertai } \\
\text { suara } \\
\text { pelafalan. } \\
\text { Disini berisi } \\
\pm 25 \text { kata } \\
\text { benda dan }\end{array}$ & & Sesuai \\
\hline
\end{tabular}




\begin{tabular}{|c|c|c|c|}
\hline $\begin{array}{c}\text { Data } \\
\text { Masukkan }\end{array}$ & $\begin{array}{l}\text { Harapan } \\
\text { Keluaran }\end{array}$ & $\begin{array}{c}\text { Hasil } \\
\text { pengamata } \\
\mathbf{n} \\
\end{array}$ & Kesimpulan \\
\hline & & $\begin{array}{l}\text { berfungsi } \\
\text { semua }\end{array}$ & \\
\hline $\begin{array}{l}\text { Tombol } \\
\text { kalimat }\end{array}$ & $\begin{array}{l}\text { Gambar disertai kalimat } \\
\text { yang ada di tengah akan } \\
\text { muncul beserta suara } \\
\text { pelafalannya } \\
\text { menyesuaikan pilihan } \\
\text { gambar yang ditekan di } \\
\text { bawahnya }\end{array}$ & $\begin{array}{l}\text { Tampil gambar } \\
\text { disertai kalimat } \\
\text { pendukung dan suara } \\
\text { pelafalan. } \\
\begin{array}{l}\text { Disini berisi } \pm 25 \\
\text { kalimat dan berfungsi } \\
\text { semua }\end{array}\end{array}$ & Sesuai \\
\hline Kuis 2 & $\begin{array}{l}\text { Pertanyaan dengan } \\
\text { memilih jawaban yang } \\
\text { tersedia }\end{array}$ & $\begin{array}{l}\text { Tampil pertanyaan } \\
\text { dan } 3 \text { opsi jawaban, } \\
\text { satu diantaranya yang } \\
\text { benar. Setiap nomor } \\
\text { soal jawaban benar } \\
\text { akan mendapatkan } \\
\text { skor }\end{array}$ & (c) \\
\hline Kuis 3 & $\begin{array}{l}\text { Pertanyaan dengan } \\
\text { jawaban harus diisi } \\
\text { mandiri }\end{array}$ & $\begin{array}{l}\text { Tampil pertanyaan } \\
\text { dan ruang jawaban } \\
\text { yang harus diisi } \\
\text { mandiri. Setiap } \\
\text { nomor soal jawaban } \\
\text { benar akan } \\
\text { mendapatkan skor }\end{array}$ & Sesuai \\
\hline
\end{tabular}

\section{KESIMPULAN}

Kesimpulan yang dapat diperoleh dari penelitian ini adalah, model pengembangan rancang bangun aplikasi media ajar ini mengadopsi dari waterfall sehingga tahapan pengerjaannya lebih terkonsep. Keberhasilan dari pembuatan aplikasi dibuktikan dengan pengujian model Black box testing, dimana semua komponen di kolom pengamatan tampilan telah sesuai dengan yang ada di tampilan harapan. Aplikasi yang dibangun mengacu ke kurikulum MI/SD dan disajikan dengan ejaan bahasa Indonesia serta gambar yang menarik. Sehingga aplikasi ini memberi muatan isi yang baru dan lebih sesuai dengan materi di tingkat pendidikan dasar.

\section{UCAPAN TERIMA KASIH}

Kepada Universitas Muhammadiyah Ponorogo melalui Lembaga Penelitian dan Pengabdian kepada Masyarakat (LPPM) yang telah mendanai penelitian melalui program Internal 2018 - 2019.

\section{DAFTAR PUSTAKA}

[1] H. G. Tarigan, Membaca Sebagai Satu Keterampilan Membaca. Bandung: Angkasa Bandung, 2008.

[2] D. Tarigan, Pendidikan Bahasa dan Sastra Indonesia di Kelas Rendah. Jakarta: Pusat Penerbitan Universitas Terbuka, 2005.

[3] C. A. F. Dewanto, "Pengembangan Media Pembelajaran Berbasis Android Pada Mata Pelajaran Teknologi Dasar Otomotif Untuk Kelas X Smk Negeri 3 Buduran - SidoarjO Cahya Arif Fredyana Dewanto Abstrak," JPTM, vol. 05, no. 03, pp. 40-46, 2016.

[4] H. Rusdi, "Pengembangan Media Pembelajaran Berbasis Android 'ChemBird Pada Materi," $J$. Ecosyst., vol. 6, no. 2, pp. 204-394, 2016.

[5] A. H. Galih Vidia Pangestika, Wawan Wikusna, "Aplikasi Pembelajaran Bahasa Inggris untuk Murid Sekolah Dasar Berbasis Android," e-Proceeding Appl. Sci., vol. 3, no. 3, pp. 1558-1575, 2017.

[6] B. R. M. Roger S Pressman, Software Engineering A Practitioner's Approach, Eight Ed. .

[7] M. S. Rosa A. S, Rekayasa Perangkat Lunak Terstruktur dan Berorientasi Objek. Bandung: Informatika Bandung, 2013.

[8] S. Novita Br Ginting, Yuggo Afrianto, "Menggunakan Metode Prototype Dan Pengujian Black Box ( Studi Kasus : Fakultas Teknik Dan Sains Universitas Ibn Khnovita Braldun )," J. Simetris, vol. 10, no. 2, pp. 577-588, 2019. 